\title{
Generative Potential of Carboniferous-Permian Coal-Bearing Source Rocks in Ordos Basin
}

\author{
Cheng Li1',2, Qing Yuan'1,2, Min Zhang1,2* \\ ${ }^{1}$ Key Laboratory of Exploration Technology for Oil and Gas Research (Yangtze University), Ministry of Education, Wuhan, China \\ ${ }^{2}$ College of Resources and Environment, Yangtze University, Wuhan, China \\ Email: ${ }^{\star} z m j p u @ 163 . c o m$
}

How to cite this paper: Li, C., Yuan, Q. and Zhang, M. (2017) Generative Potential of Carboniferous-Permian Coal-Bearing Source Rocks in Ordos Basin. Open Journal of Yangtze Gas and Oil, 2, 260-272.

https://doi.org/10.4236/ojogas.2017.24021

Received: July 21, 2017

Accepted: October 27, 2017

Published: October 30, 2017

Copyright $\odot 2017$ by authors and Scientific Research Publishing Inc. This work is licensed under the Creative Commons Attribution International License (CC BY 4.0).

http://creativecommons.org/licenses/by/4.0/

\begin{abstract}
The organic matter abundance, type and maturity have been studied along with their generative potential in coals, carbonaceous mudstones and mudstones from Carboniferous-Permian in Ordos Basin, revealing that the coal-bearing source rocks in the study area have the stronger generative potential. The source rocks are typically humic gas source rocks with the main source rock dominated by the coals. There are significant diversities in the generative potential in different lithological source rocks. The generative potential decreases in the following order: coals, carbonaceous mudstones, mudstones. The desmocollinite in vitrinite group shows a positive correlation with hydrogen index $\left(I_{\mathrm{H}}\right)$ or $S_{1}+S_{2}$ values, indicating the desmocollinite in coal may be the major contributor to hydrocarbon generation. On the whole, the hydrogen index and $S_{1}+S_{2}$ values both exhibit a good relationship with the desmocollinite in carbonaceous mudstones or mudstones, whereas they have a poor correlation with the pristane/phytane ratios. The hydrogen index and $S_{1}+S_{2}$ values in coal with the increased pristane/phytane ratios in coal both increase at first and then decrease, whereas they both have a poor correlation with the desmocollinite. These results show that the generative potential in coal is mainly related with the sedimentary environment, while the hydrocarbon generation matter is the main factor influencing the generative potential in carbonaceous mudstones or mudstones.
\end{abstract}

\section{Keywords}

Ordos Basin, Carboniferous-Permian, Coal-Bearing Source Rocks, Generative Potential

\section{Introduction}

The Ordos Basin is the China's second largest petroliferous basins, with long 
evolution time, big sedimentary thickness, lots of reservoir types and abundant oil and gas resources, which has a broad exploration areas and good development prospects [1] [2]. Its Upper-Paleozoic has considerable amounts of natural gas. So far, the majority of large oil and gas fields have been successively discovered in Ordos Basin, such as Yilin, Sulige, Wushenqi, and Mizhi [3] [4] [5].

It is an indisputable fact that the considerable amounts of Upper-Paleozoic natural gas are primarily from the Upper-Paleozoic coal-measure strata [6] [7] [8]. Many scholars have studied the development characteristics of source rocks from different aspects or angles, and then determined the main source rock interval and distribution in the study area [7] [8]. Xu et al. (2009) [7] confirmed that the coal bed from Upper-Paleozoic was the main gas source in the study area, based on researching the hydrocarbon generation capacity of source rocks in Hangjinqi block. According to the evaluation on the organic matter abundance, type, maturity and hydrocarbon generation capacity, the similar conclusion was carried out by Ji et al. (2013) [8]. However, the reasons why the main source rock in the study area is coal and the coal can generate hydrocarbon are few reported in the domestic and overseas literature.

Although the large amounts of experiments and researches on the hydrocarbon from coals have been made [9] [10] [11] [12], there are many arguments for the confirmation of the main contributor to hydrocarbon derived from coal. The abundance of fluorescing vitrinite and resinite was considered to be responsible for that [9]. Based on the previous researches on the hydrocarbon-generating in coal from Turpan basin, there were two different kinds of theories about the main hydrocarbon-generating substance in coal [13] [14]. The one was that the desmocollinite was the significant contributor to hydrocarbon from coal [10] [12]. Another one was that the major hydrocarbon-generating substances in coal might be the suberinite [11]. However, Huang et al. (1996) [15] also proposed that the bitumen in coal measures might also be the main contributor to hydrocarbon generation in accordance with the studies on structural chemistry. According to the ultra stratigraphic organic petrology, Wang (1995) [16] and Zhao et al. (1997) [17] noted that the submicroliptinite in desmocollinite was the main hydrocarbon generating substances in coal and considered that the cause of hydrogen richness in desmocollinite attributed to strong degradation and reworking of bacteria to it in the biochemical stage. Alternative explanation was the stronger degradation of phytoclasts in clastic sediments as compared to the peat environment where woody particles were better preserved [18]. In this case, more hydrogen-rich plant debris such as resinite, saporiniteect, could be possibly preserved as macerals in coal.

However, Zhao et al. (1985) [19] noted that the redox of sedimentary environment was the "third factor" that affected the coal quality. Zhao et al. (1997) [20] considered that the hydrogen-rich component content in coal depended on the sedimentary environment.

Hence, the main aim of this paper is to discuss the organic matter abundance, 
type and maturity in coal-measure source rocks with the emphasis on the diversity in coal-measure source rock generative potential and their main controlling factor on the basis of previous studies about the coal-generated hydrocarbons, which provides the theoretical foundation for the hydrocarbon generation mechanism in coal.

\section{Geological Setting}

The Ordos basin, located in western North China Platform, is the second largest sedimentary basin in China, covering an area of about 250,000 $\mathrm{km}^{2}$ (Figure 1). It is surrounded by the Yanshan Mountains in the north, the Qinling Mountains in the south, the Liupanshan Mountains in the west and the Luliangshan Mountains in the east. The basin can be divided into six structural units: the Yimeng uplift, Weibei uplift, Western edge thrusting belt, Tianhuan depression, Shanbei slope, and the Jinxi flexural fold belt (Figure 1) [2].

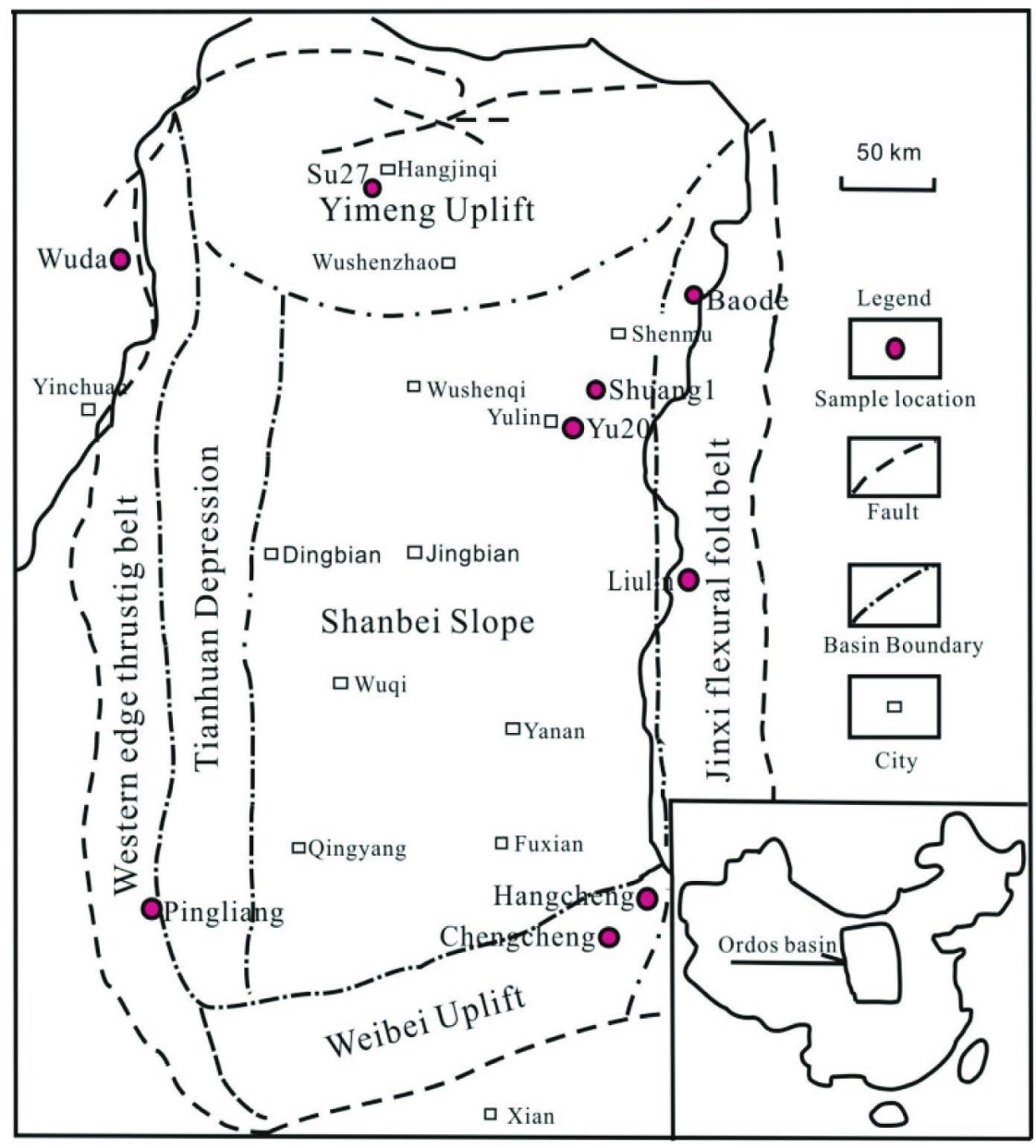

Figure 1. Map showing the location of samples and structural units of the Ordos Basin.

Since the Middle Paleozoic, the Ordos Basin has experienced five discernable stages, including a Middle-Late paleozoic aulacogen basin, an Early Paleozoic 
marginal basin, a Late Paleozoic intracration basin, a Mesozoic renamentcratonic basin and a Cenozoic rift basin [1]. From the present study, the existence of the marine transgressive events has been recognized as important and typical representative events during the Carboniferou-Permian periods [1] [2]. During the Carboniferous period, the Ordos Basin was featured by lagoon and tidal-flat facies, whereas it was dominated by the marine-continental trasitional facies and fluvial-lacustrine faces in Perimian period [21]. The Carboniferous-Permian strata, from bottom to top, consist of the Upper Carboniferous Benxi formation, Lower Permian Taiyuan formation and Shanxi formation, Upper Permian Lower Shihezi formation, Upper Shihezi formation, and Shiqianfeng formation.

\section{Samples and Methods}

\subsection{Samples}

A total of 119 samples from Carboniferous-Permian coal-bearing source rocks were collected from the Pingling, Wuda, Baode, Liulin, Hancheng, Chengcheng outcrop profiles and dill cuttings of Shuang 1, Yu 20 and Su 27 wells (Figure 1). Analysis of the contents of total organic carbon and Rock-Eval pyrolysis were applied to all samples (Table 1). Twenty-seven coal-measure source rock samples were selected for maceral analysis (Table 2 and Figures 2-4). Forty-nine samples were also selected for bitumen extractions (Table 1).

Table 1. Total organic carbon, rock-eval pyrolysis, and Chloroform bitumen " $A$ " Results for coal-measure source rocks from carboniferous-permian in Ordos Basin.

\begin{tabular}{ccccc}
\hline Lithology & TOC $/ \%$ & $S_{1}+S_{2} /\left(\mathrm{mg} \cdot \mathrm{g}^{-1}\right)$ & $I_{\mathrm{H}} /\left(\mathrm{mg} \cdot \mathrm{g}^{-1}\right)$ & Chloroform bitumen “A” (\%) \\
\hline \multirow{2}{*}{ Mudstone } & $0.11-5.91$ & $0.04-9.25$ & $3-143$ & $0.004-0.088$ \\
& $2.13(67)$ & $0.85(67)$ & $29.12(67)$ & $0.024(17)$ \\
& $2.61-27.90$ & $0.25-34.70$ & $1-224$ & $0.004-0.234$ \\
Carbonaceous $^{*}$ & $12.08(22)$ & $6.93(22)$ & $51.82(22)$ & $0.072(12)$ \\
& $33.05-77.61$ & $0.13-389.89$ & $1-562$ & $0.013-1.143$ \\
Coal & $53.06(30)$ & $73.09(30)$ & $148.69(30)$ & $0.371(20)$ \\
\hline
\end{tabular}

Note: Carbonaceous ${ }^{*}=$ Carbonaceous mudstone.

Table 2. The analysis results of maceral composition, $R_{\mathrm{o}}$ and $t_{\max }$ on coal-bearing source rocks from carboniferous-permian in Ordos Basin.

\begin{tabular}{|c|c|c|c|c|c|c|}
\hline \multirow[b]{2}{*}{ Lithology } & \multicolumn{3}{|c|}{ Organic maceral volume fraction $/ \%$} & \multirow{2}{*}{$\begin{array}{c}\text { Type Index } \\
T_{\mathrm{i}} / 1\end{array}$} & \multirow[b]{2}{*}{$R_{\mathrm{o}} / \%$} & \multirow[b]{2}{*}{$t_{\max } /{ }^{\circ} \mathrm{C}$} \\
\hline & Vitrinite & Intertinite & $\begin{array}{c}\text { Exinite + } \\
\text { Sapropelic }\end{array}$ & & & \\
\hline \multirow{2}{*}{ Mudstone } & $65.45-100$ & $0-16.67$ & $0-33.33$ & \multirow{2}{*}{$-1.25--43.9$} & $0.66-1.59$ & $423-568$ \\
\hline & $86.07(9)$ & $7.86(9)$ & $5.46(9)$ & & $1.00(17)$ & $501(67)$ \\
\hline \multirow{2}{*}{ Carbonaceous $^{*}$} & $55.86-99.08$ & $0-35.29$ & $0-7.84$ & \multirow{2}{*}{$-16.1--36.2$} & $0.70-1.58$ & $431-562$ \\
\hline & $86.67(5)$ & $10.70(5)$ & $2.62(5)$ & & $1.17(6)$ & $494(22)$ \\
\hline \multirow{2}{*}{ Coal } & $63.73-98.70$ & $0-25.49$ & $0-14.29$ & \multirow{2}{*}{$-1.63--66.65$} & $0.72-1.31$ & $432-554$ \\
\hline & $86.57(13)$ & $10.14(13)$ & $3.29(13)$ & & $1.00(7)$ & $474(30)$ \\
\hline
\end{tabular}




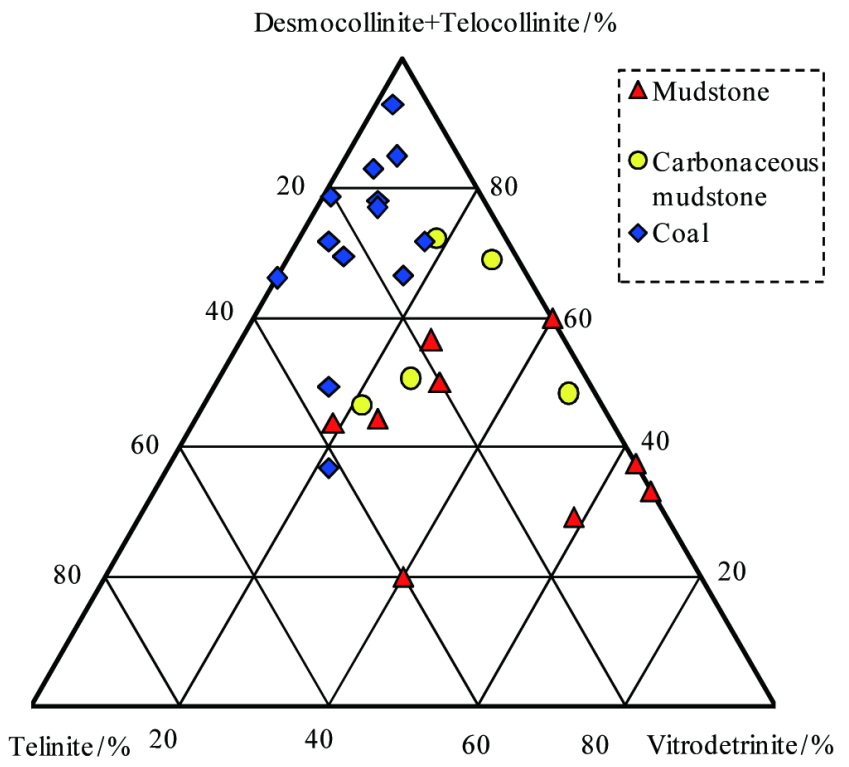

Figure 2. Ternary diagram showing the relative content of dedmocollinite and telocollinite, telinite, and vitrodetrinite in vitrinite of coal-measure source rocks from carboniferous-permian in Ordos Basin.

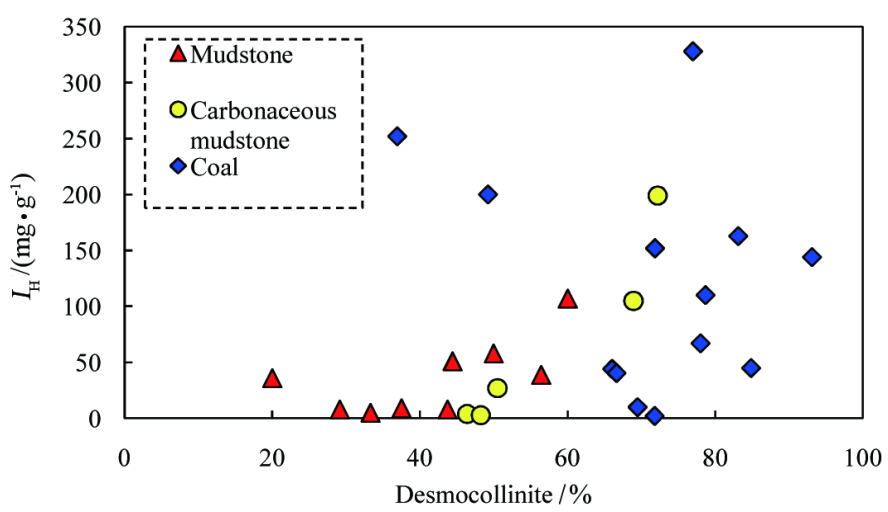

Figure 3. Cross-plot of the desmocollinite vs. hydrogen index of the coal-bearing source rocks from carboniferous-permian in Ordos Basin.

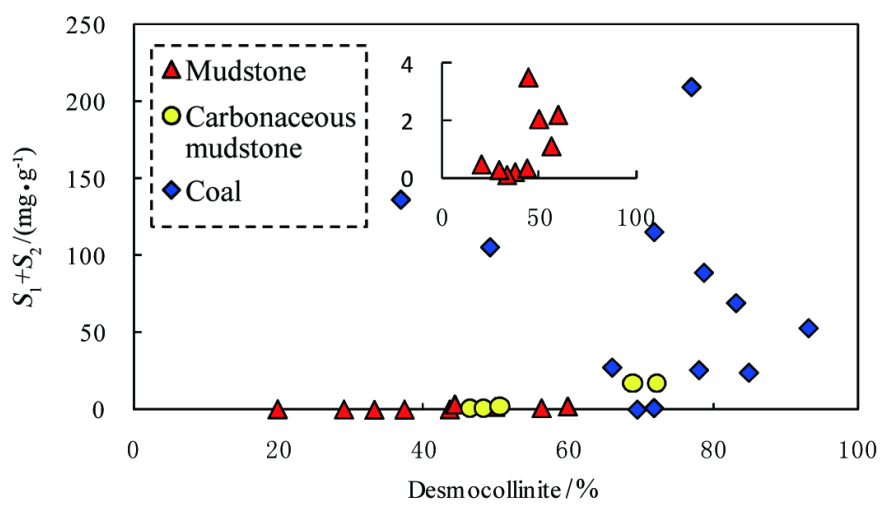

Figure 4. Cross-plot of the desmocollinite vs. $S_{1}+S_{2}$ values of the coal-bearing source rocks from carboniferous-permian in Ordos Basin. 


\subsection{Analytical Methods}

For microscopic investigations, the samples were crushed to a maximum size of 1-mm. Maceral analysis was performed by a single-scan method [22] with a Leica DMRX microscope using reflected white and fluorescent light. And the measurement of reflectance was made on polished resin-embedded whole rock blocks with a Leica MPV-SP photomicroscope. At least 30 points were counted and the results are given in Table 2. Vitrinite macerals were classified according to the nomenclature by Sykorova et al. (2005) [23]. Maceral percentages were used to calculate kerogen type indicators. The type index $\left(I_{\mathrm{H}}\right)$ is useful organic matter type indicator and were calculated for the Ordos Basin samples according to the following formulas:

$$
T_{\mathrm{i}}=(\text { sapropelic } \times 100+\text { exinite } \times 50+\text { vitrinite } \times(-75)+\text { inertinite } \times(-100)) / 100
$$

All samples were crushed into fine power and analyzed for their contents of total organic carbon and Rock Eval pyrolysis. The total carbon content was determined on a LECO CS-2000 induction furnace. The organic content was measured with the same instrument on samples pretreated with concentrated hydrochloric acid. Pyrolysis was carried out on the collected samples using a Delsi Rock Eval instrument Version REVI. As a pyrolysis maturation indicator, the temperature of maximum hydrocarbon generation $\left(t_{\max }\right)$ was measured.

Bitumen extractions were preformed on 49 samples using a Soxhlet apparatus for $72 \mathrm{~h}$ with a dichloromethane/methanol mixture $(93: 7 \mathrm{v} / \mathrm{v})$. The results are given in Table 1. Then, the extracted bitumens were fractionated into saturated, aromatic hydrocarbons, NSOs (nitrogen, sulfur and oxygen) and asphaltenes using open column chromatography. Only the saturated fractions were analyzed in this study. Saturated hydrocarbons were analyzed using gas chromatography-mass spectrometry (GC-MS) in full scan mode. GC-MS was carried out with a HP-5Ms fused silica capillary column $(30 \mathrm{~m} \times 0.25 \mathrm{~mm}$ i.d., film thicknesses $0.25 \mu \mathrm{m}$ ). The GC temperature was programmed to start at $50^{\circ} \mathrm{C}$ for 1 min, increase to $100^{\circ} \mathrm{C}$ at a rate of $20^{\circ} \mathrm{C}$, and from $100^{\circ} \mathrm{C}$ to $310^{\circ} \mathrm{C}$ at a rate of $3^{\circ} \mathrm{C} / \mathrm{min}$ with a final fold of $18 \mathrm{~min}$. Helium was used as the carrier gas with a rate of $1.0 \mathrm{ml} / \mathrm{min}$ and the ionization source operated at $70 \mathrm{eV}$. For the analysis of the effects of sedimentary environment on the generative potential, the pristane and phytane were identified in their diagnostic ion chromatograms on the basis of relative retention times.

\section{Results and Discussion}

\subsection{Bulk Compositions and Properties}

\subsubsection{Organic Matter Abundance}

It can be observed that the coals of Carboniferous-Permian in Ordos Basin have the highest TOC (total organic carbon) values in Table 1, ranging from 33.05\% to $77.61 \%$, with an average of $53.06 \%$. While the carbonaceous mudstones display the lower TOC values, varying in range of $2.61 \%-27.90 \%$, averaging 
$12.08 \%$. The $T O C$ values of mudstones are the lowest, varying between $0.11 \%$ and $5.91 \%$, with an average of $2.13 \%$. The variation in their $S_{1}+S_{2}$ values is consistent with that of TOC values. The $S_{1}+S_{2}$ values of most coal samples are greater than $60 \mathrm{mg} / \mathrm{g}$. While the $S_{1}+S_{2}$ values carbonaceous mudstones and mudstones range from 0.25 to $34.70 \mathrm{mg} / \mathrm{g}$ and 0.04 to $9.25 \mathrm{mg} / \mathrm{g}$, with an average of $6.93 \mathrm{mg} / \mathrm{g}$ and $0.85 \mathrm{mg} / \mathrm{g}$, respectively. Interestingly, the chloroform extract yields of coal-measure source rocks exhibit the similar variation. According to the evaluation criteria of coal-measure source rocks raised by Liu et al. (1987) [24], the coal bed in the study area are fair to good source rocks, whereas the carbonaceous mudstones and mudstones belong to the worse source rocks.

\subsubsection{Organic Matter Type}

Macerals are recognizable constituents of kerogen that can be differentiated as to type of organic matter by their morphology [25]. The Carboniferous-Permian coal-bearing source rocks in Ordos basin studied have higher amounts of vitrinite (Table 2), ranging from $55.86 \%$ - $100 \%$ with an average of $86.42 \%$. The similar maceral composition distribution in mudstones, carbonaceous mudstones and coals can be observed. Most samples have a characteristic of the vitrinite content more than $70 \%$ and dominated by desmocollinite. While the coal-bearing source rocks display the lower and variable intertinite, exinite and sapropelic content. The inertinite content of coal-bearing source rocks ranging from $0 \%$ $32.59 \%$ with an average of $9.49 \%$, while the exinite and sapropelic content of most samples are abnormally low, varying in rang of $0 \%-33.33 \%$, averaging $3.95 \%$. These phenomena may indicate that the Carboniferous-Permian coal-bearing source rocks in Ordos Basin are typically humic [26]. A type index $T_{\mathrm{i}}$ between $(-66.66)-(-1.25)$ lower than zero is estimated for coal-bearing source rocks based on the contribution of the macreal composition to hydrocarbon, indicative of the kerogen of source rocks belonging to the humic-rich type [27].

\subsubsection{Organic Matter Maturity}

The level of thermal maturation can be estimated from vitrinite reflectance $\left(R_{\mathrm{o}}\right)$ and maximum temperature of $S_{2}\left(t_{\max }\right)$ [28]. The similar thermal evolution of the mudstones, carbonaceous mudstones and coals in Ordos Basin can be observed in Table 2. The vitrinite reflectance of mudstones ranges from $0.72 \%$ to $1.31 \%$ with an average of $1.00 \%$, while their $t_{\max }$ values are between $423^{\circ} \mathrm{C}$ and $568^{\circ} \mathrm{C}$, having an average of $501^{\circ} \mathrm{C}$, indicating that the mudstones are mainly at mature-highly mature stage. The carbonaceous mudstones have a feature of the vitrinite reflectance and $t_{\max }$ at a rang of $1.05 \%-1.58 \%$ and $431^{\circ} \mathrm{C}-562^{\circ} \mathrm{C}$, averaging $1.17 \%$ and $494^{\circ} \mathrm{C}$, respectively, indicative of the mature-highly mature organic matter. While the coals are characterized by vitrinite reflectance and $t_{\max }$ varying between $0.66 \%-1.63 \%$ and $432^{\circ} \mathrm{C}-554^{\circ} \mathrm{C}$, with an average of $1.00 \%$ and $474^{\circ} \mathrm{C}$, respectively, reflecting that the coals are significantly mature-highly mature. Although their $R_{\mathrm{o}}$ values and $t_{\max }$ values both vary widely, they all reveal that the organic matters in the study area are at mature-highly mature stage. 


\subsection{The Main Factors of the Generative Potential for Coal-Bearing Source Rocks}

\subsubsection{The Generative Potential Distribution in Different Lithology Source Rocks}

The Rock-Eval hydrogen index $\left(I_{\mathrm{H}}\right)$ values or $S_{1}+S_{2}$ values can reflect changes in hydrocarbon generative potential [28] [29]. There is a big difference between the $S_{1}+S_{2}$ values for the coal-bearing source rocks described above. Their $S_{1}+S_{2}$ values decrease in the following order: coals, carbonaceous mudstones, mudstones. It is interesting that the similar change in hydrocarbon index exists in coal-bearing source rocks (Table 1). The coals as well as carbonaceous mudstones exhibit variable hydrogen indexes, mostly obviously higher than mudstones. Most coal samples have a hydrogen index more than $150 \mathrm{mg} / \mathrm{g}$ with an average of $148.69 \mathrm{mg} / \mathrm{g}$. The hydrogen indexes of carbonaceous mudstones are between 1 and $224 \mathrm{mg} / \mathrm{g}$, having an average of $51.82 \mathrm{mg} / \mathrm{g}$. The mudstones display the lower hydrogen indexes, mostly less than $50 \mathrm{mg} / \mathrm{g}$, with an average of $29.12 \mathrm{mg} / \mathrm{g}$. According to the distribution of $S_{1}+S_{2}$ values and hydrogen index, we can ascertain that the generative potential of coal-bearing source rock decreases in the following order: coals, carbonaceous mudstones, mudstones.

\subsubsection{The Effects of Maceral Composition on the Generative Potential}

As well known, the vitrinite, including the telinite, desmocollinite, telocollinite and vitrodetrinite, is the primary maceral component in terrestrial source rocks. It is also the most abundant organic maceral component in coal-meaasure source rocks. The vitrinite ternary diagram (Figure 2) shows that most samples have the higher percentage of desmocollinite and telocollinite and the lower vitrodetrinite. The desmocollinite and telocollinite content of most coal samples are greater than $60 \%$ with the maxmiun reaching about $84.92 \%$. The carbonaceous mudstones are characterized by desmocollinite and telocollinite at the range of $46.46 \%-69 \%$. While the mudstones have a feature of the desmocollinite and telocollinite content less than $60 \%$, ranging from $20 \%$ to $60 \%$. Meanwhile, the distribution of desmocollinite and telocollinite is similar with the generative potential in coal-measure source rocks, indicating that the desmocollinite or telocollinite in coal-measures may be the major hydrocarbon generation substances.

However, the questions that the desmocollinite or telocollinite in coal-measure source rocks can generate hydrocarbon in Ordos Basin are few reported. These questions will be discussed in this paper through the relationships between the desmocollinite and $S_{1}+S_{2}$ values or hydrogen index $\left(I_{\mathrm{H}}\right)$ in coal-measure source rocks (Figure 3, Figure 4). Figure 3 illustrates the relationship of the desmocollinite content and hydrogen index. Apart from two coal samples having the higher hydrogen index with lower desmocollinite content, the desmocollinite content of all other samples shows a good linear correlation with the hydrogen index. Figure 4 shows the relationship of the desmocollinite content and $S_{1}+S_{2}$ values. An excellent correlation between the desmocollinite content and $S_{1}+S_{2}$ 
values can also be observed in this diagram. In addition, the relative content of telocollinite in coals, carbonaceous mudstones and mudstones are generally lower than $0.1 \%$. The $S_{1}+S_{2}$ values in coals are higher than that of carbonaceous mudstones and mudstone described above. The generative potential of coals is respectively 18.13 times and 119.30 times that of carbonaceous mudstones and mudstones. Meanwhile, the coals have the higher desmocollinite content than carbonaceous mudstones and mudstones. It reveals that the desmocollinite in coal-measures is the major contributor to hydrocarbon generation. The hydrogen-rich property of desmocollinite from coal-measures in the study area is more likely to be concerned with the microbial action. It was thought that the desmocollinite in coal was formed by the fermentation of anaerobic metabolism in a strongly reduced environment [19]. Zhao et al. (1994) [30] also considered that the hydrogen-rich property of desmocollinite in coal was related to the degradation and modification of bacteria and other microorganisms.

The desmocollnite in carbonaceous mudstones respectively exhibits a positive correlation with hydrocarbon index and $S_{1}+S_{2}$ values, while the correlation coefficients are respectively 0.903 and 0.987 (Figure 3 and Figure 4). It suggests that the generative potential in carbonaceous mudstones that is mainly affected by the generating hydrocarbon matters. As shown in Figure 3 and Figure 4, although the hydrogen index and $S_{1}+S_{2}$ values in mudstones are lower, respectively ranging from 5 to $107 \mathrm{mg} / \mathrm{g}$ and 0.10 to $3.51 \mathrm{mg} / \mathrm{g}$, they both have a relatively general correlation with the desmocollinite contents, corresponding to the $\mathrm{r}^{2}$ values of 0.410 and 0.382 , respectively. It indicates that the sedimentary environment other than the generating hydrocarbon matter may also account for the generative potential in mudstones. The poor correlations of the hydrogen index and $S_{1}+S_{2}$ values with desmocollinite contents in coals are illustrated in Figure 3 and Figure 4, corresponding to the $\mathrm{r}^{2}$ values of 0.125 and 0.114 , respectively. Zhao et al. $(1985 ; 1992 ; 1994)$ noted that the redox of sedimentary environment was the "third factor" that affected the coal quality [19] [26] [31]. Zhao et al. (1997) considered that the hydrogen-rich component content in coal depended on the sedimentary environment [32]. Hence, the generative potential in coals may be mainly related to sedimentary environment.

\subsubsection{The Effects of Sedimentary Environment on the Generative Potential}

As for the coal bed, its generative potential has not been reflected by the organic matter abundance, whereas the nature of coal is more likely to reflect the difference of hydrocarbon generation properties. The main factors influencing coal quality are generally the maceral composition and the metamorphic degree of coal. However, a lot of researches show that considerable amounts of coals having the similar maceral compositions exhibited the variable generative potential. Hence, Zhao et al. $(1985 ; 1992 ; 1994)$ noted that the redox of sedimentary environment was the "third factor" that affected the coal quality [19] [26] [32]. 
According to Dikyk et al. (1978) [33], pristane/phytane ratios below 1.0 indicate anaerobic conditions during early diagenesis, and values between 1.0 and 3.0 were interpreted as reflecting dysaerobic environments. The pristane/phytane ratio $(\mathrm{Pr} / \mathrm{Ph})$ for the investigated coal-measure samples ranges from 0.27 to 5.29 (Figure 5). Almost all of the values are between 1.0 and 3.0, indicating relatively dysaerobic depositional conditions for the majority of the coal-measures. It can be observed that the linear correlations between the pristane/phytane ratios and $S_{1}+S_{2}$ values or hydrogen index $\left(I_{\mathrm{H}}\right)$ in carbonaceous mudstones or mudstones are relatively poor, while the $S_{1}+S_{2}$ values and the hydrogen index $\left(I_{\mathrm{H}}\right)$ values in coals increase at first and then decrease with the elevated pristaine/phytane ratios (Figure 5). The $S_{1}+S_{2}$ values and hydrogen indexes $\left(I_{\mathrm{H}}\right)$ reach the maximum at the pristane/phytane ratio about 2.07 . In addition, the coals are typically humic in the study area described above. Therefore, the generative potential in liptobiolith deposited in different sedimentary environment is diverse, attaining the maximum at the weak-reduced environment. The abundance of hydrofluoroscopicvitrinite in different depositional environment can be responsible for that (Zhao et al., 1992) [32]. While the generative potential of carbonaceous mudstones and mudstones are not affected by sedimentary environment. It may suggest that the generative potential of carbonaceous mudstones and mudstones are mainly related to hydrocarbon generation substances.

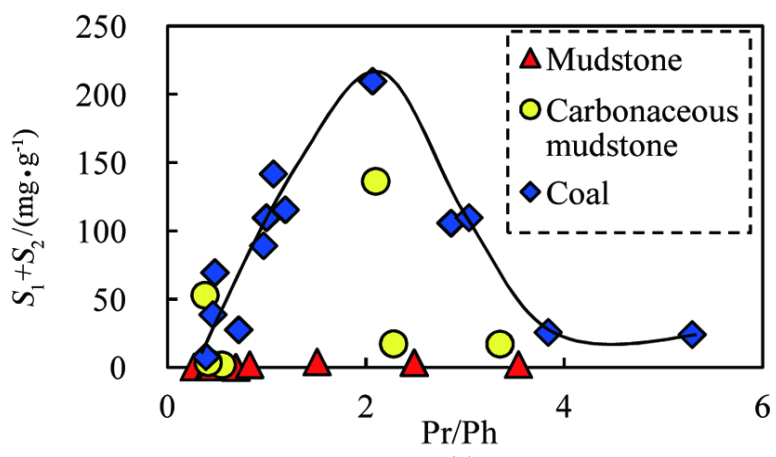

(a)

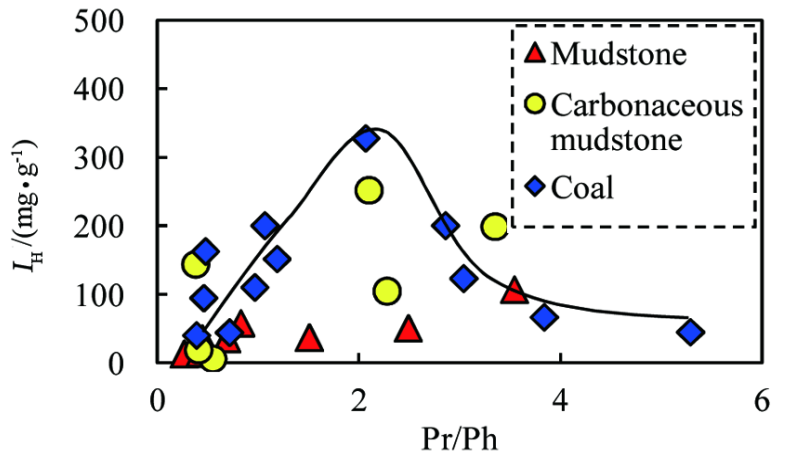

(b)

Figure 5. Plot of pristine/phytane vs. $S_{1}$ and $S_{2}$ values and hydrogen index $\left(I_{\mathrm{H}}\right)$ of the coal-bearing source rocks from Carboniferous-Permian in Ordos basin. 
In conclusion, the content of desmocollinite in carbonaceous mudstones and mudstones in the study area both exhibit a better linear correlation with hydrogen index or $S_{1}+S_{2}$ values than that of coals. It is interesting that the $S_{1}+S_{2}$ values and the hydrogen index $\left(I_{\mathrm{H}}\right)$ values in coals increase at first and then decrease with the increasing reduced environment, while the $S_{1}+S_{2}$ values and the hydrogen index $\left(I_{\mathrm{H}}\right)$ values in carbonaceous mudstones or mudstones show a relatively poor relationship with the pristane/phytane ratios. It suggests that the generative potential in carbonaceous mudstones or mudstones is more likely related to the desmocollinite, which may be associated with the degradation and modification of bacteria and other microorganisms. While the sedimentary environment accounts for the generative potential in coals.

\section{Conclusion}

The coal-bearing source rocks of Carboniferous-Permian in Ordos Basin are evaluated based on conventional geochemical methods, such as the organic matter abundance, type and maturity. The source rocks in the study area are typically humic gas source rocks with the main source rocks dominated by the coals. The generative potential in coals, carbonaceous mudstones and mudstones are distinctly different. The generative potential decreases in the following order: coals, carbonaceous mudstones, mudstones. A good linear correlation exists between the desmocollinite in coal-bearing source rocks and the hydrogen index $\left(I_{\mathrm{H}}\right)$ or $S_{1}+S_{2}$ values. The hydrocarbon generation substance of coal-measures in the study area is the desmocollinite. Its hydrogen-rich property is related with the degradation and modification of bacteria and other microorganisms. Overall, the desmocollinite content of carbonaceous mudstones and mudstones respectively exhibits a excellent and general correlation with the hydrogen index and $S_{1}+S_{2}$ values, while the poor correlations exist between the desmocollinite content in coals and hydrogen index or $S_{1}+S_{2}$ values. Meanwhile, the generative potential of coal in the study area is mainly affected by the redox environment, increasing at first and then decreasing with the elevated reductibility. While the generative potential of carbonaceous mudstones and mudstones are not affected by sedimentary environment. It suggests that the generative potential in coals is mainly related with the sedimentary environment, while the generative potential in carbonaceous mudstones or mudstones is more likely to be associated with hydrocarbon generation substances.

\section{Acknowledgements}

This study was financially supported by the National Natural Science Foundation of China (Grant No. 41772124) and National Science and Technology Major Projects (2016ZX05007-001-002).

\section{References}

[1] He, Z.X. (2003) Evolution and Hydrocarbon of Ordos Basin. Petroleum Industry 
Press, Beijing.

[2] Yang, J.J. (2002) Tectonic Evolution and Oil-Gas Reservoirs Distribution in Ordos Basin. Petroleum Industry Press. Beijing.

[3] Yang, H. Fu, J.H. and Wei, X.S. (2008) Sulige Field in the Ordos Basin: Geological Setting, Field Discovery and Tight Gas Reservoirs. Marine and Petroleum Geology, 25, 387-400. https://doi.org/10.1016/j.marpetgeo.2008.01.007

[4] Dou, W.T., Liu, X.H. and Wang, T. (2010) The Origin of Formation Water and the Regularity of Gas and Water Distribution of the Sulige Gas Field, Ordos Basin. Actapetrolei Sinica, 31, 767-773.

[5] Yang, X.Y., Shen, Z.G., Fang, S.X., Hou, F.H. and Fu, S.H., et al. (2007) Sedimentary Characteristics of Beach and Bar Sandbodies in the Lower Submember of Member 8 of Xiashizi Formation of Middle Permian in Wushenqi Gasfield Ordos Basin. Journal of Paleogeography, 9, 175-183.

[6] Dai, J.X., Li, J., Hu, G.Y., Luo, X. and Tao, S.Z., et al. (2005) Geochemical Characters of the Giant Gas Accumulations with over One Hundred Billion Cubic Meters Reserves in China. Petroleum Exploration and Development, 32, 16-23.

[7] Xu, B., Nie, H.K., Wang, M., Zhang, Y.W. and Liu, J.N. (2009) A Study of Hydrocarbon-Generating Potential of Hangjinqi Prospect Area in Ordos Basin. Petroleum Geology and Recovery Effciency, 16, 38-40.

[8] Ji, W.M., Li, W.L., Liu, Z. and Lei, T. (2013) Research on the Upper Paleozoic Gas Source of the Hangjinqi Block in the Northern Ordos Basin. Natural Gas Geoscience, 24, 905-914.

[9] Horsfield, B., Yordy, K.L. and Crelling, J.C. (1988) Determining the Petroleum-Generating Potential of Coal Using Organic Geochemistry and Organic Petrology. Organic Geochemistry, 13, 121-129. https://doi.org/10.1016/0146-6380(88)90032-0

[10] Zhao, C.Y. and Cheng, K.M. (1995) The Organic Petrology Characteristics of Oil Derived from Coal in Turpan-Hami Basin. Petroleum Exploration and Development, 22, 24-27.

[11] Huang, D.F., Qin, K.Z. and Wang, T.K. (1995) The Formation and Mechanism of Coal-Derived Oil. Petroleum Industry Press, Beijing.

[12] Liu, Y.Q., Feng, Q. and Hao, J.N. (2002) Discussion on Oil Derived Coal in the Jurassic Oil Pool in Turpan-Hami Basin. Oil and Gas Geology, 23, 326-331.

[13] Chen, Z.K. and Hu, S.H. (1996) Relationship between Inertinite in Coal and Accumulation and Migration of Oil from Coal. Petroleum Exploration and Development, 23, 25-27.

[14] Huang, D.F., and Lu, S.F. (1999) Current Situation and Prospect in Geochemistry of Oil from Coals. Earth Science Frontiers, 6, 183-194.

[15] Huang, D.F. and Xiong, C.W. (1996) Generation, Migration and Evaluation of Hydrocarbon Generation Potential of Oil Formed in Coal-Bearing Strata. Explorationist, No. 2, 6-11.

[16] Wang, F.Y. (1995) Submicro-Level Organic Petrology and Application in the Assessment of Source Rocks. Journal of the University of Petroleum, No. S1, 112-117.

[17] Zhao, C.Y., Cheng, K.M. and Wang, F.Y. (1997) Analyses of the Macerals Contributing Mainly to Hydrocarbons Derived from Coals of the Turpan-Hami Basin. Acta Sedimentologica Sinica, 15, 95-99.

[18] Jasper, K., Krooss, B.M., Flajs, G., Hartkopf-Fröder, C. and Littke, R. (2009) Cha- 
racteristics of Type III Kerogen in Coal-Bearing Strata from the Pennsylvanian (Upper Carboniferous) in the Ruhr Basin, Western Germany: Comparison of Coals, Dispersed Organic Matter, Kerogen Concentrates and Coal-Mineral Mixtures. International Journal of Coal Geology, 80, 1-19.

[19] Zhao, S.Q. (1985) A Preliminary Discussion of the Genesis of Humic Bituminous Coal in Special Reference to Its Reductibility. Geochimica, 4, 363-370.

[20] Zhao, C.Y. (1997) Hydrocarbon Generation from Jurassic Coal and Coaly Organic Matters in Turpan-Hami Basin. Petroleum Exploration and Development, 24, 23-27.

[21] Chen, H.D., Hou, Z.J., Tian, J.C., Liu, W.J. and Zhang, J.Q. (2001) Study on Sequence-Stratigraphy of Deposits and Tectono-Sedomentary Evolution in Ordos Basin during Late Paleozoic. Journal of Mineralogy and Petrology, 21, 16-22.

[22] Taylor, G.H., Teichmüller, M., Davis, A.C.F.K., Diessel, C.F.K., Littke, R. and Robert, P. (1998) Organic Petrology. Borntraeger, Berlin-Stuttgart, 704 p.

[23] Sýkorová, I., Pickel, W., Christanis, K., Wolf, M., Taylor, G.H. and Flores, D. (2005) Classification of Huminite-ICCP System 1994. International Journal of Coal Geology, 62, 85-106.

[24] Liu, D.H. and Fu, J.M. (1985) Geochemical Characteristics of Coal-Generated Hydrocarbon. Geology Press, 195-198.

[25] Li, X.Q., Ma, A.L. and Zhong, N.N. (1997) Organic Petrology Research Method and Application of Source Rock. Chong University Press, 72-80, 120-127.

[26] Zhao, S.Q. and Wang, F.Y. (1994) Discussion on the "Sedimentary Environment-Type of Coal-Forming Charateristics of Coal Quality” Rough Genetic Model: Environment and Coal Racies. Acta Sedimentologica Sinica, 12, 32-39.

[27] Shang, H.Y. (1990) Organic Geochemistry and Fluorescent Microscope Techniques. Petroleum Industry Press.

[28] Petrs, K.E. (1986) Guidelines for Evaluating Petroleum Source Rock using Programmed Pyrolysis. Aapg Bulletin, 70, 318-329.

[29] Chen, J.P., Zhao, C.Y. and He, Z.H. (1997) Criteria for Evaluating the Hydrocarbon Generating Potential of Organic Matter in Coal Measures. Petroleum Exploration and Development, 24, 1-5.

[30] Zhao, C.Y. and Jin, K.L. (1994) The Generative Potential and Characteristic of the Desmocollinite in Coal from Turpan Basin. Science in China, 39, 1979-1981.

[31] Zhao, C.Y. (1997) Hydrocarbon Generation from Jurassic Coal and Coaly Organic Matters in Turpan-Hami Basin. Petroleum Exploration and Development, 24, 23-27.

[32] Zhao, S.Q. and Wang, F.Y. (1992) Study on Hydrocarbon-Generating Potential of Different Types of Reducting Humic Coal and Its Vitrinites. Journal of China Coal Society, 4, 101-110.

[33] Didyk, B.M., Simoneit, B.R.T., Brassell, S.C. and Eglinton, G. (1978) Organic Geochemical Indicators of Palaeoenvnonmental Conditions of Sedimentation. Nature, 272, 216-222. https://doi.org/10.1038/272216a0 